\title{
Correlation of Ultrasonographic Findings with Operative Findings in Acute Appendicitis
}

\author{
Santhosh Babu Rendla ${ }^{1}$, Narender Reddy Peddareddy ${ }^{1}$, \\ Sumalatha Kasturi $^{2 *}$ and Sandhya Rani Bojjam ${ }^{3}$ \\ ${ }^{1}$ Department of Radiology, Chalmeda Anand Rao Institute of Medical Sciences, \\ Karimnagar, Telangana State, India \\ ${ }^{2}$ Department of Pathology, Chalmeda Anand Rao Institute of Medical Sciences, Karimnagar, \\ Telangana State, India \\ ${ }^{3}$ Department of Dermatology and Venereology, Mamatha Medical College, Khammam, \\ Telangana State, India \\ *Corresponding author
}

\begin{tabular}{|c|c|}
\hline & A B S T R A C T \\
\hline & \multirow{7}{*}{$\begin{array}{l}\text { To study the incidence, age and sex distribution of acute appendicitis in patients } \\
\text { with right lower quadrant pain and correlation of ultrasonographic findings with } \\
\text { operative findings in acute appendicitis. This study was under taken from } \\
\text { December } 2013 \text { to December } 2015 \text {. Total number of cases studied were } 100 \text { and } \\
\text { controls were } 50 \text { and this includes both out patients attending the Department of } \\
\text { Surgery, CAIMS, Karimnagar. The cases were clinically diagnosed as acute } \\
\text { appendicitis. The controls were selected randomly from the patients who were } \\
\text { admitted in surgery Department other than clinical suspicion of acute appendicitis. } \\
\text { More than } 63 \% \text { of cases occurred in } 2^{\text {nd }} \text { and } 3^{\text {rd }} \text { decade and males were more } \\
\text { affected than females Commonest US feature was target sign and commonest } \\
\text { position of appendix was retro caecal appendix. False negatives were } 3 \text {, false } \\
\text { positive was } 1 \text {. Sensitivity of our study was } 96.20 \% \text { and specificity of study was } \\
95.23 \% \text {. Positive predictive value was } 98.70 \% \text { and Negative predictive value was } \\
86.95 \% \text {. P-value of our study was } 0.0001 \text {. Ultrasonography should be the primary } \\
\text { imaging procedure for patients suspected to have acute appendicitis. Sonography is } \\
\text { also helpful in detecting of complications of appendicitis and for other abdominal } \\
\text { diseases that mimic appendicitis. }\end{array}$} \\
\hline $\begin{array}{l}\text { K e y w o r d s } \\
\text { Ultrasonography, } \\
\text { Appendicitis, } \\
\text { Target sign. }\end{array}$ & \\
\hline Article Info & \\
\hline & \\
\hline Available Online: & \\
\hline & \\
\hline & \\
\hline
\end{tabular}

\section{Introduction}

Acute appendicitis is the most common surgical abdominal emergency in India. Adolescents are most prone for acute appendicitis.
Any mortality in this age group because of delay in diagnosis or delay in treatment can affect the wealth of the family and also the wealth of the nation. So it is a challenging 
problem for both diagnosing physician and surgeon.

In about $30 \%$ of patients the signs, symptoms and laboratory findings of acute appendicitis are atypical (Blane et al., 1986) often leading to delay in diagnosis and surgical intervention and consequent increase in the rate of perforation. Although the mortality rate of uncomplicated cases of appendicitis may be as low as $0.1 \%$ is rises to $13 \%$ appendiceal perforation (Bailey). In addition other disease produce clinical and laboratory findings similar to that of acute appendicitis leading to negative appendectomy rate of 20 to $25 \%$ (Soter et al., 1973) this rate is particularly high $35 \%$ to $46 \%$ of for female patients during their reproductive years because of various gynecologic diseases (Takada et al., 1986).

Of the imaging studies used to diagnose appendicitis plain films have been most frequently used however although several plain film signs or used in the diagnosis, findings are neither specific nor sensitive except for the occasional Appendicolith (Feldberg et al., 1985).

Barium enema has also been used to diagnose acute appendicitis. However its accuracy is limited (Abu-Yousef et al., 1987). Both computed tomography (Johnmaa) and Indium 111 leukocyte scintigraphy (Puylaert, 1986) are advocated to evaluate patients suspected of having acute appendicits. But these are not available in most of hospitals and also relatively expensive so these are usually reserved for complicated cases.

Sonography has previously been shown to helping the diagnosis of appendiceal abscesses (Bailey) and other diseases with a clinical presentation similar to that of acute appendicitis. Recently with the introduction of real time and high resolution sonography direct visualization of the acutely inflamed appendix has become possible (Puylaert, 1986; Karstrup et al., 1986; Jeffery et al., 1987).

\section{Materials and Methods}

This study was under taken from December 2013 to December 2015. Total number of cases studied were 100 and controls were 50 and this includes both out patients attending the Department of Surgery, CAIMS, Karimnagar.

The cases were selected after clinical examination which shows pain and tenderness in right lower quadrant (RLQ) clinically diagnosed as acute appendicitis.

The controls were selected randomly from the patients who were admitted in surgery Department other than clinical suspicion of acute appendicitis. sonographic pattern of disease in patients with right lower quadrant pain, probe tenderness, free fluid in right iliac fossa, diameter of appendix, appendicular muscle wall thickness, appendicolith in patients of acute appendicitis were studied.

The incidence, age and sex distribution of acute appendicitis and correlation of ultrasonographic findings with operative findings in acute appendicitis were studied.

\section{Results and Discussion}

All 100 patients presented with pain in right lower quadrant. 47 patients associated with vomitings and 41 patients associated with fever. 
This study consists of patients having age between 0 - 80 years. The total number of male patients were 60 and female were 40 .

Highest number of patients susceptible to acute appendicitis are the age group $11-20$ year.

Ultrasonographic examination of acute appendicitis is one of the recent non invasive imaging technique. Though the medical ultrasound was invogue since middle 1950's its present exponential increase in the clinical value in diagnosis of acute appendicitis due to evoluation of graded compression technique by Puylaert JBCM in 1986.

Basically ultrasonography is a dynamic real time imaging technique without any hazardous of ionization with that X-Rays. It is cost effective investigation and not much time consuming it can be used safely in pregnancy also.

For patients with RLQ pain in the question had to be answered whether the pain is really due to acute appendicitis or other diseases which mimic acute appendicitis.

The clinical presentation of acute appendicitis is typical in more than $70 \%$ of patients. Above $30 \%$ of patients have an uncertain preoperative diagnosis. Consequently the rate of unnecessary laparotomy for acute appendicitis is as high as $20-25 \%$. The rate is even higher $35-45 \%$ in women of child bearing age group because of pelvic inflammatory disease and complicated pregnancies. So ultrasonographic examination of RLQ is necessary for these patients. This is the basis for our study.

Our study comprised 100 unselected patients admitted in Surgery Department, CAIMS with suspected acute appendicitis. These include 60 males and 40 females, these 100 patients were examined clinically, radiologically and ultrasonographically. Ultrasonography was performed immediately after admission. Ultrasound was repeated in a few cases, these cases were treated surgically or by conservatively depending on the condition of the patient. They were followed up over a period till they were discharged. We have also studied 50 unselected patients admitted in the Surgery Department of radiology other than clinical suspicion of acute appendicitis as controls.

Among the 100 cases studied 75 cases proved surgically were acute appendicitis. 4 cases were appendicular mass, 4 cases were pelvic inflammatory disease, 3 cases were right ureteric calculus, 1 case was right acute pylenoephritis, 2 cases were ileocaecal tuberculosis, 2 cases were carcinoma caecum. 1 case was twisted ovarian cyst, 1 case was Crohn's ileitis and no abnormally was detected in 7 patients.

\section{Male: Female ratio in acute appendicitis}

In our study among the 75 cases of acute appendicitis, 45 patients were males and 30 patients were females. For appendicular mass 3 patients were males and 1 patient was female, the male: female was 1:54:1(Table-I).

\section{Age incidence in acute appendicitis}

In our study highest number of patients with acute appendicitis in the age group of 1-20 years, and constitutes $41.7 \%$ total cases. The next affected age group was 21-30 years, and constitutes $21.5 \%$ of total cases, the youngest patient in our study was 2 years, and oldest patient was 67 years old. Mean age of our patient was 23 years. 
According to R.B. Jeffrey Jr. et al., (1988) study mean age was 26 years.

According to M.Galindo Lallego et al., study mean age was 21.8 years.

\section{Location of Appendix}

In our study we have observed retrocaecal appendix in $60(75.9 \%)$ cases, pelvic in 14 (17.7\%) cases, subcaecal in 2 cases $(2.5 \%)$, perileal in 1 case $91.26 \%$ ), post ileal in 1 case $(1.26 \%)$ and subhepatic in 1 case $(1.26 \%)$.

According to Wakeley et al., 1993 study retrocaecal and retrocolic in $65.28 \%$ pelvic $31.01 \%$. Subcaecal in $2.26 \%$ preileal in $1 \%$, postileal in $0.4 \%$.

\section{Diameter of Appendix}

In our study we have taken the maximum outer of the normal appendix was $6 \mathrm{~mm}$ as a sonographic criteria. Mean diameter of appendix in our study was $9.56 \mathrm{~mm}$.

M.M. Abu-yousef et al., (1987) study they have taken maximum outer diameter of the normal appendix was $6 \mathrm{~mm}$ as a sonographic criteria.

Table.1 Sex incidence of acute appendicitis and Appendicular Mass

\begin{tabular}{|c|c|c|c|}
\hline Disease & Males & Females & No. Patients \\
\hline Acute Appendicitis & 45 & 30 & 75 \\
\hline Appendicular Mass & 3 & 1 & 4 \\
\hline Total & 48 & 31 & 79 \\
\hline
\end{tabular}

Table.2 Age incidence of acute appendicitis and appendicular mass

\begin{tabular}{|c|c|c|}
\hline Age & No. of Patients & Percentage \% \\
\hline $0-10$ & 12 & 15.18 \\
\hline $11-20$ & 33 & 41.77 \\
\hline $21-30$ & 17 & 21.51 \\
\hline $31-40$ & 5 & 6.32 \\
\hline $41-50$ & 7 & 8.86 \\
\hline $51-60$ & 3 & 3.78 \\
\hline $61-70$ & 2 & 2.53 \\
\hline Total & $\mathbf{7 9}$ & $\mathbf{1 0 0 \%}$ \\
\hline
\end{tabular}

Highest number of patients susceptible to acute appendicitis are the age group $11-20$ year.

Table.3 Sonographic Findings

\begin{tabular}{|c|c|}
\hline Finding & No. of cases \\
\hline Target sign & 76 \\
\hline Probe Tenderness & 72 \\
\hline Free Fluid & 27 \\
\hline Appendicolith & 10 \\
\hline
\end{tabular}


Table.4 Calculation of sensitivity and specificity

\begin{tabular}{|c|c|c|}
\hline Sonographic diagnosis & Patients with disease & Patients without disease \\
\hline Positive & $76(\mathrm{a})$ & $1(\mathrm{~b})$ \\
\hline Negative & $3(\mathrm{c})$ & $20(\mathrm{~d})$ \\
\hline
\end{tabular}

Total number of cases $\quad$ - $\quad 100$

Sonographically positive for appendicitis - $\quad 77$

Sonographically negative $\quad-\quad 23$

False Positive $\quad-\quad 1$

False negative $\quad-3$

a $\quad 76$

1. Sensitivity $=\frac{}{a+c} \times 100=\frac{}{76+3} \times 100=96.20 \%$

d 20

2. Specificity $=\frac{}{d+b} \times \quad 100=\frac{}{20+1} \times 100=95.23 \%$

a $\quad 76$

$\begin{aligned} & \text { 3. } \begin{array}{l}\text { Predictive value }=\longleftarrow \\ \text { of positive test }\end{array} \\ & a+b\end{aligned} \quad 100=\frac{100=98.70 \%}{3+20}$

d 20

4. Predictive valve $=\longleftarrow$ X $100=\frac{}{3+20} \times 100=86.95 \%$
Of Negative test 
Table.5 Comparative results of different studies

\begin{tabular}{|l|c|c|c|c|c|c|}
\hline References & $\begin{array}{l}\text { Frequency } \\
\text { Transducer }\end{array}$ & $\begin{array}{c}\text { Accuracy } \\
(\%)\end{array}$ & $\begin{array}{c}\text { Sensitivity } \\
(\%)\end{array}$ & $\begin{array}{c}\text { Specificity } \\
(\%)\end{array}$ & $\begin{array}{l}\text { Predictive } \\
\text { Value(+ve)\% }\end{array}$ & $\begin{array}{l}\text { Predictive } \\
\text { Value(-ve) } \%\end{array}$ \\
\hline $\begin{array}{l}\text { Puylaert } \\
\text { et al., (1986) }\end{array}$ & $5 / 7.5 \mathrm{MHz}$ & -- & 75 & 100 & -- & -- \\
\hline $\begin{array}{l}\text { Kastrup } \\
\text { et al.,(1986 }\end{array}$ & $5 \mathrm{MHz}$ & 87 & 83 & 94 & 96 & 76 \\
\hline $\begin{array}{l}\text { Monzer } \\
\text { et al., (1987) }\end{array}$ & $5 \mathrm{MHz}$ & 90 & 80 & 95 & 91 & 89 \\
\hline $\begin{array}{l}\text { RB Jeffery } \text { et } \\
\text { al., (1987) }\end{array}$ & $5 \mathrm{MHz}$ & 93.9 & 89.9 & 96.2 & 93 & 94.3 \\
\hline $\begin{array}{l}\text { Wolf } \text { } \text { et al., } \\
\text { (1989) }\end{array}$ & $5 \mathrm{MHz}$ & 95.7 & 88.5 & 98 & 94.5 & 96.3 \\
\hline $\begin{array}{l}\text { Harshada } \\
\text { M.Joshi } \text { et al., }\end{array}$ & $\begin{array}{c}6.5 . / 10 \mathrm{Mhz} \\
1996)\end{array}$ & 95 & 96 & 93 & 98 & 88 \\
\hline $\begin{array}{l}\text { Present } \\
\text { study(2005) }\end{array}$ & $8 \mathrm{Mhz}$ & 94 & 96.2 & 95.2 & 98.7 & 86.9 \\
\hline
\end{tabular}

Table.6 Position of appendix noted in our series

\begin{tabular}{|c|c|c|}
\hline Appendix position & No. of cases & Percentage \\
\hline Retro caecal & 60 & 75.95 \\
\hline Pelvic & 14 & $17.7 \%$ \\
\hline Sub caecal & 2 & $2.5 \%$ \\
\hline Pre ileal & 1 & $1.26 \%$ \\
\hline Post ileal & 1 & $1.26 \%$ \\
\hline Sub hepatic & 1 & $1.26 \%$ \\
\hline Total & $\mathbf{7 9}$ & $\mathbf{1 0 0 \%}$ \\
\hline
\end{tabular}

Table.7 Control Study

\begin{tabular}{|c|c|c|}
\hline Appendix position & No. of cases & Percentage \\
\hline Retro caecal & 60 & 75.95 \\
\hline Pelvic & 14 & $17.7 \%$ \\
\hline Sub caecal & 2 & $2.5 \%$ \\
\hline Pre ileal & 1 & $1.26 \%$ \\
\hline Post ileal & 1 & $1.26 \%$ \\
\hline Sub hepatic & 1 & $1.26 \%$ \\
\hline Total & $\mathbf{7 9}$ & $\mathbf{1 0 0 \%}$ \\
\hline
\end{tabular}


Table.8 P - Value

\begin{tabular}{|l|c|c|c|}
\hline & US Positive & US Negative & \\
\hline $\begin{array}{l}\text { Patients with } \\
\text { Disease }\end{array}$ & 76 & 3 & 79 \\
\hline $\begin{array}{l}\text { Patients without } \\
\text { Disease }\end{array}$ & 3 & 47 & 50 \\
\hline & 79 & 50 & 129 \\
\hline
\end{tabular}

Analysis of single table odds ration $=396.89(64.54)$

$\begin{array}{lll} & \text { Chi }- \text { square } & \mathrm{P}=\text { Value } \\ \text { Corrected } & 101.20 & 0.0001\end{array}$

Fig.1, 2 Ultrasonographic findings of acute appendicitis
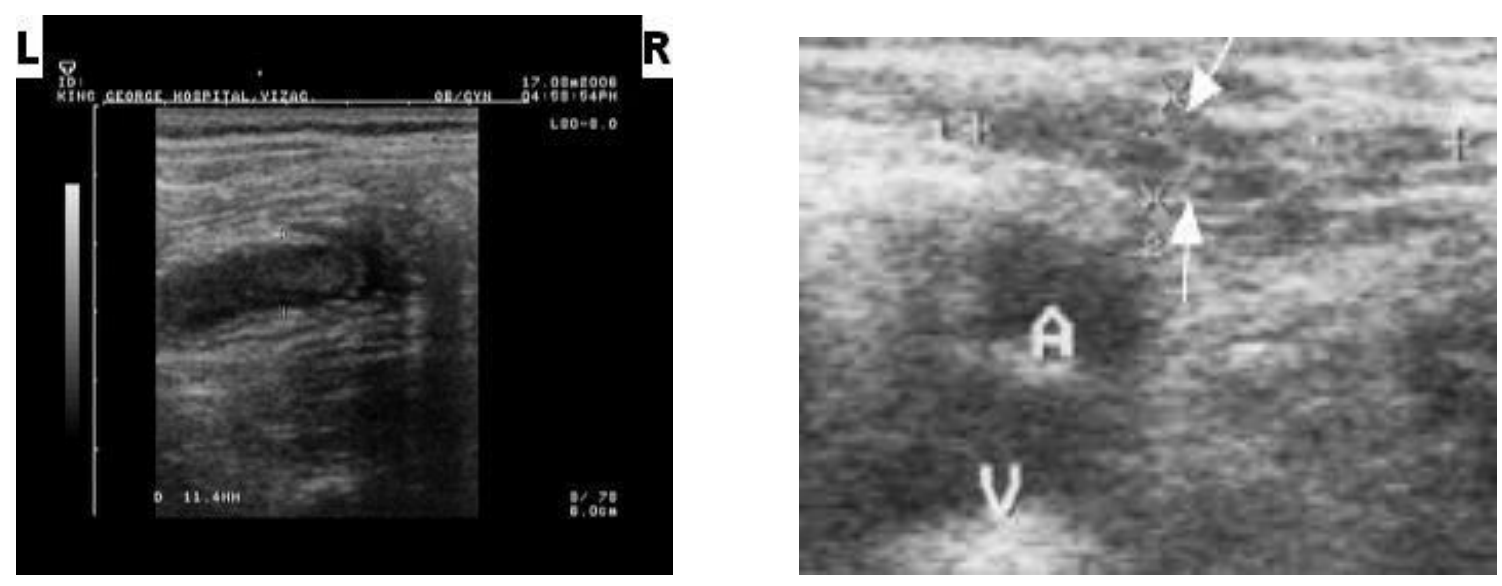

Fig.3, 4 Intra operative findings of acutely inflamed appendix.
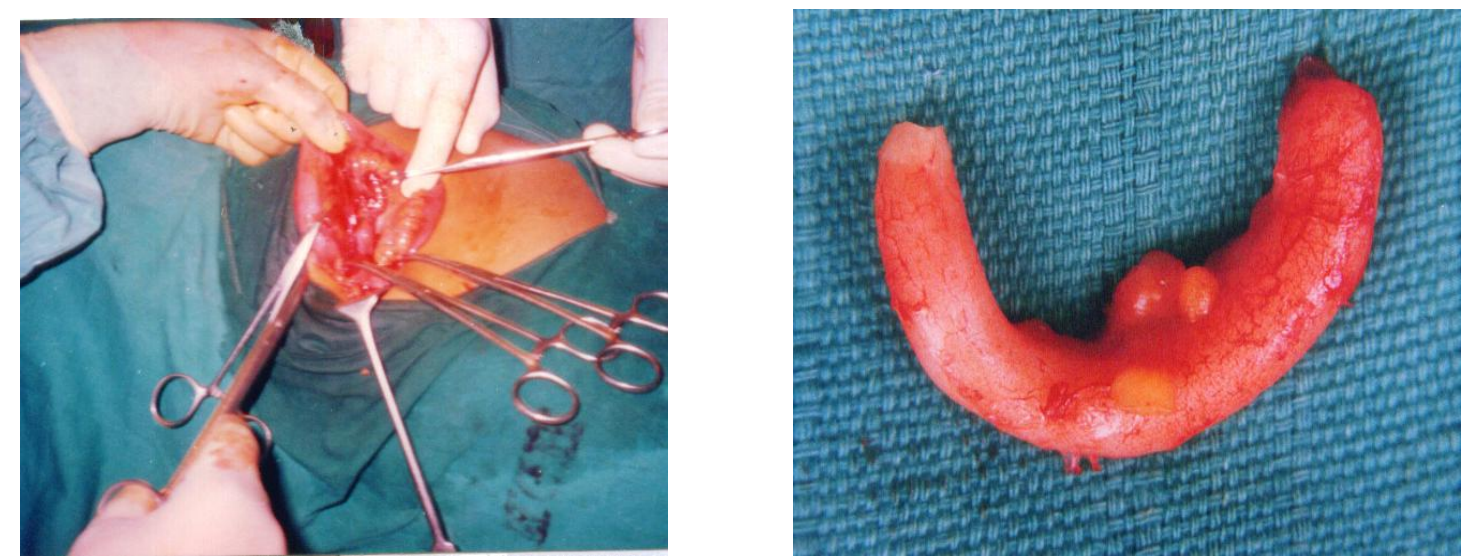


\section{Muscle wall thickness of the appendix}

In our study we have taken hypo echoic muscle wall thickness more than $2.5 \mathrm{~mm}$ as a criteria for acute appendicitis. Mean muscle wall thickness in our study was $3.01 \mathrm{~mm}$.

R.K. Singh et al., study they have taken muscle wall thickness more than or equal to $2.5 \mathrm{~mm}$ as a criteria for acute appendicitis.

Miland Gune et al., study they have taken muscle wall thickness more than $3.9 \mathrm{~mm}$ as a criteria for acute appendicitis.

\section{Sensitivity}

In our study role of ultrasonography in diagnosis of acute appendicitis sensitivity was $96.2 \%$.

According to R.B. Jeffrey Jr. et al., (1988) study sensitivity was $89.9 \%$.

According to Harshd M. Joshi et al., (1996) study sensitivity was $96 \%$. In our study the sensitivity was correlating with the above reported series.

\section{Specificity}

In our study role of ultrasonography in diagnosis of acute appendicitis specificity was 95.2\%. R.B. Jeffrey Jr. et al., (1998) study specificity was $96.2 \%$ Harshada M. Joshi et al., (1996) reported specificity of 93\% in their series. Puylaert et al., (1986) reported $100 \%$ specificity in their series. So in our study the specificity was correlating with the above reported series.

\section{False Negativity}

In our study false negativity of $3.8 \%$ was noted. These patients were obese with thick abdominal wall so we could not locate the appendix. These were proved to be retrocaecal appendix at surgery.
In H.M. Joshi et al., (1996) study a false negativity of $4 \%$ reported.

\section{False Positivity}

In our study false positivity of $1.2 \%$ was noted. Crohn's ileitis of terminal ileum was mistaken as an inflamed appendix. In H.M. Joshi et al., (1996) study a false positivity of 2\% was noted. An inflamed Meckel's diverticulum was mistaken as an inflamed appendix in their patient.

\section{Predictive value of positive test}

In our study role of ultrasonography in diagnosis of acute appendicitis predictive value of negative test was $86.9 \%$ in R.B. Jeffrey et al., (1987) study it was $94.3 \%$ in H.M. Joshi et al., (1996) study it was $88 \%$, so in our study predictive value of negative test was correlating with the above reported series.

\section{Control study}

We have studied 50 patients admitted in Surgery Department other that appendicitis. In our study normal appendix was visualized in 6 patients (12\% of cases). Appendix diameter less than $6 \mathrm{~mm}$ in 3 cases (6\%), and more than $6 \mathrm{~mm}$ in 3 cases $(6 \%)$, in these three patients 2 patients were having ascites of different causes.

In Hyo K. Lin et al., 1994 studied normal appendix was visualized in $16 \%$ of normal individuals. In Ann Jones and Paul Dubbins et al., study normal appendix was visualized in $30 \%$ of normal individuals.

\section{P - Value}

In our study p-value $<0.001$ was noted. According to Zielke et al., 1998 study pvalue was $<0.001$. 
According to Hahn et al., 1999 study pvalue was <0.001. According to Ford et al., 1994 study p-value was $<0.05$ so our study was correlating with above reporting series.

In conclusion, ultrasonography is a dynamic real time imaging technique without any hazards of ionization such as with X-rays. It is a cost effective investigation and not much time consuming. It can be used in bedside examination in critically ill patients. It can be used safely in pregnancy also.

Because of its high accuracy, sonography should be the primary imaging procedure for patients suspected to have acute appendicitis. Sonography is also helpful in detecting of complications of appendicitis and for other abdominal diseases that mimic appendicitis.

\section{References}

Abu-Yousef, M.M., Bleicher, J.J., Maher, J.W. et al. 1987. High - resolution sonography of acute appendicitis. AJR, 149: $53-58$.

Bailey \& love's short practice of Surgery, $23^{\text {rd }}$ edition. Edited by R.C.G. Russell, N.S. Williams.

Bailey, Norman, S., Williams, Christopher, J.K., Bulstrore, 2013. Bailey and Love's short practice of surgery.26 th edition.CRC Press, NewYork, Page No.1200-1214..
Blane, C.E., White, S.J., Wesely, J.R., et al., 1986. Sonography of ruptured appendicitis. Gastrointest. Radiol., 11: $357-360$.

Feldberg, M.A.M., Hendriks, M.J., van Waes, P.F.G.M. 1985. Computed tomography in complicated acute appendicitis. Gastrointest. Radiol., 10: $289-295$.

Jeffery, R.B. Jr. Laing, F.C., Lewis, F.R. 1987. Acute appendicitis: High resolution real-time US findings. Radiol., 163: 11- 14.

Johnmaa, Kimberly, S., Kirkwood. 2013. Sabiston Text book of Surgery.19 th edition. Elsevier. Page No.s 12791289.

Kai, S.C.S., Smith, W.L., Abu - Yousef, M.M. et al. Sonographic findings in acute appendicitis in children. AJR.

Karstrup, S., Trop - Pedersen, S.S., Roikjaer, O. 1986. Ultrasonic visualization of the inflamed appendix. Br. J. Radiol., 59: 985 - 986.

Puylaert, J.B.C.M. 1986. Acute appendicitis: US evaluation using graded compression. Radiol., 158: 355 - 360 .

Soter, C.S. The contributions of the radiologist to the diagnosis of acute appendicitis. Semin roentgenol., 8: 375 $-388$.

Takada, T., Yasuda, H., Uchiyama, K., et al. 1986. Ultrasonographic diagnosis of acute appendicitis in surgical indication. Int. Surg., 71: 9-31.

\section{How to cite this article:}

Santhosh Babu Rendla, Narender Reddy Peddareddy, Sumalatha Kasturi and Sandhya Rani Bojjam. 2016. Correlation of Ultrasonographic Findings with Operative Findings in Acute Appendicitis. Int.J.Curr.Microbiol.App.Sci. 5(7): 836-844.

doi: http://dx.doi.org/10.20546/ijcmas.2016.507.096 